\title{
Dinosaurs and pterosaurs in Greek and Roman art and literature? An investigation of young-earth creationist claims
}

\author{
Phil Senter
}

\begin{abstract}
Many young-Earth creationist (YEC) authors claim that ancient Greek and Roman writings describe dinosaurs and pterosaurs, and that Greco-Roman art illustrates Mesozoic reptiles. Such claims are used as "evidence" against evolutionary theory in an attempt to cast doubt on the separation of humans and such animals by millions of years. However, examination of the Greco-Roman materials in question reveals that none of them actually depict Mesozoic reptiles. In descriptions of "dragons" (Greek drakōn; Latin draco) in Greco-Roman literature-which YEC authors claim are dinosaurs-coils and the epithets ophis, serpens, and anguis reveal that the ancient authors are describing snakes, often large constrictors. This is the case for the draco described by Pliny. Phrygian dragons described by Aelian, the Vatican Hill child-eater mentioned by Pliny, the Bagradas River dragon, the legendary dragons that Alexander the Great supposedly encountered, and dragons in Greek mythology. An alleged theropod dinosaur in the Nile Mosaic of Palestrina is a mammal, possibly an otter. An alleged dinosaur in a Pompeii fresco is a crocodile. Herodotus' description of winged snakes is anatomically incompatible with pterosaurs and possibly refers to cobras. Alleged pterosaurs on an Alexandrian coin are winged snakes. An alleged Etruscan pterosaur head sculpture depicts a mammal. Two alleged Tanystropheus in a Roman mosaic from Lydney Park, England are mythical sea monsters. These YEC claims now join the ranks of discredited "evidence" against evolutionary theory.
\end{abstract}

Phil Senter. Department of Biological Sciences, Fayetteville State University, 1200 Murchison Road, Fayetteville, North Carolina 28301, USA, psenter@uncfsu.edu

KEY WORDS: creationism; dragon(s); dinosaur(s); pterosaur(s); Pliny; Herodotus; krokodilopardalis; Tanystropheus 


\section{INTRODUCTION}

"Evidence" of human encounters with living dinosaurs and pterosaurs has become an important part of the arsenal of the anti-evolution movement. It is used to support the young-Earth creationist (YEC) view by casting doubt on the separation of humans and such animals by millions of years. According to the YEC view, the Earth and all kinds of organisms were independently created about 6000 years ago, as described in the book of Genesis. In contrast, scientists generally accept the physical evidence that the Earth is approximately 4.6 billion years old (Gradstein et al., 2004) and that all organisms evolved from a common ancestor (e.g., Prothero, 2007). Nonetheless, the YEC view remains popular in North America and parts of Europe (Mazur, 2005; Miller et al., 2006) and is taught in private schools across the United States. Even in U.S. public high schools one in eight biology teachers explicitly endorses the YEC view in class (Berkman and Plutzer, 2011). Because so many children are taught YEC "evidence" involving dinosaurs and pterosaurs at a young age in grade school, it is imperative to investigate that "evidence" so that its correct nature is publicly exposed, whenever possible.

In a plethora of publications-including gradeschool science textbooks (A Beka Book, 1994; Batdorf and Porch, 2007)-YEC authors claim that dragon legends are based on human encounters with living dinosaurs and pterosaurs, and that ancient and medieval illustrations of dragons are depictions of dinosaurs and pterosaurs that were seen by people in centuries past (Gish, 1977; Rouster, 1978; Taylor, 1987; Ham et al., 1990; Niermann, 1994; Cooper, 1995; Goertzen, 1998; Morris, 1999; Petersen, 2002; Ham, 2006; Woetzel, 2006; Butt and Lyons, 2008; Lyons and Butt, 2008; Stuckwish, 2009; Isaacs, 2010; Gilmer, 2011; Nelson, 2011). According to such authors, human encounters with such animals cast doubt upon their separation from humans by millions of years, which in turn casts doubt upon an old Earth and therefore upon the common descent of all organisms, which requires an old Earth.

Many such authors refer to specific writings and artwork of the ancient Greco-Roman world as evidence of human encounters with living dinosaurs, pterosaurs, and other reptiles now known only from Mesozoic fossils (Taylor, 1987; Ham et al., 1990; Niermann, 1994; Goertzen, 1998; Zillmer, 1998; Morris, 1999; Petersen, 2002; Ham, 2006; Woetzel, 2006; Butt and Lyons, 2008; Lyons and Butt, 2008; Stuckwish, 2009; Isaacs, 2010;
Gilmer, 2011). Here, I review those specific claims, as well as the artwork and literature upon which they are based, along with other relevant classical literature, so as to test each claim of the presence of dinosaurs and other Mesozoic reptiles in ancient Greco-Roman literature and art. It is important to test YEC claims, rather than dismiss them out of hand, so that for any such claim that is refuted, the refutation is shown to be well founded and therefore not dismissible itself.

Below, where I give information from ancient Greek and Roman texts, I cite the passage in the ancient text itself (e.g., the references to Sextus Empiricis, Aelian, and Pliny in the paragraphs below) rather than citing the modern publication in which I found the transcript of the ancient text. For my sources of Greek and Latin transcripts of ancient texts, often accompanied by English translations, see Table 1. Following convention, titles of Latin works are rendered here in Latin; titles of Greek works are rendered in English; and a title with more than one word is abbreviated in citations following the first citation of the work. For such abbreviations, see Table 1.

Many, although not all, of the YEC claims examined here involve dragons in Greco-Roman literature and art. The Greek and Latin cognates of

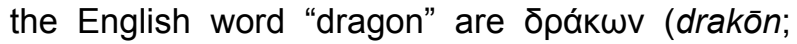
plural: ठрaкоvтєs, drakontes) and draco (plural: draconum), respectively. These words are often translated "snake" or "serpent." However, for this study, it is important not to initially dismiss every drakōn or draco in an ancient account as a mere snake, for several reasons. First, to do so is to avoid a true test of the dinosaur/pterosaur hypothesis. Second, in reference to ordinary snakes Greco-Roman writers typically use the generic

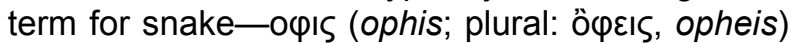
in Greek, serpens or anguis (plural: serpentes, angues) in Latin-whereas descriptions of a drakōn or draco often indicate an enormous animal that is more impressive than the average snake. Third, because drakōn and draco are used as names for the venomous-spined marine fishes of the weever family, Trachinidae (Aelian, On the Characteristics of Animals 14.12; Pliny, Naturalis Historia 9.45), the terms do not always refer to snakes. Here, therefore, I identify a drakōn or draco as a snake only if it is also called an ophis or serpens or anguis, or if it is described as having snake-specific characteristics such as limblessness, bodily coils, or resemblance to a specific type of snake. 
TABLE 1. Sources of transcripts of ancient Greek and Roman literature, with abbreviations of titles in parentheses. Titles of Latin works are given in Latin, and titles of Greek works are given in English.

\begin{tabular}{|c|c|}
\hline Author, title, and abbreviation & Source \\
\hline Aelian (Claudius Aelianus), On the Characteristics of Animals (ChA) & Scholfield 1958 \\
\hline Ammianus Marcellinus, Rerum Gestarum & Perseus 2012 \\
\hline anonymous, Hymn to Apollo & West 2003 \\
\hline Apollodorus, Library & Perseus 2012 \\
\hline Aristotle, History of Animals (HA) & Remacle 2012 \\
\hline Arrian, Indika & Perseus 2012 \\
\hline Augustine of Hippo, On Psalm 148 & Schaff 2012 \\
\hline Aulus Gellius, Noctes Atticae & Perseus 2012 \\
\hline Berossus, collected surviving works & Cory 1828 \\
\hline Cicero (Marcus Tullius Cicero), De Natura Deorum & Stickney 1881 \\
\hline Diodorus Siculus, Bibliotheca Historica & Perseus 2012 \\
\hline Florus (Lucius Annaeus Florus), Epitome Rerum Romanorum & Perseus 2012 \\
\hline Herodotus, Histories & Hare 2010 \\
\hline Hesiod, The Shield of Herakles & Perseus 2012 \\
\hline Hesiod, Theogony & Perseus 2012 \\
\hline Homer, Iliad & Perseus 2012 \\
\hline Isidore of Seville, Etymologiae & Thayer 2003 \\
\hline John of Damascus, On Dragons & Migne 1865 \\
\hline Josephus (Flavius Josephus), Jewish Antiquities & Perseus 2012 \\
\hline Justin (Marcus Junianus Justinus), Historiarum Philippicarum (HPh) & Latin Library 2012 \\
\hline Orosius (Paulus Orosius), Historiae Adversum Paganos & Latin Library 2012 \\
\hline Pliny the Elder, Naturalis Historia $(\mathrm{NH})$ & Perseus 2012 \\
\hline Plutarch, Alexander & Perseus 2012 \\
\hline Pomponius Mela, De Chorographica & Parthey 1867 \\
\hline Quintus Curtius Rufus, Historiae Alexandri Magni (HAM) & Perseus 2012 \\
\hline Sextus Empiricis, Adversus Mathematicos I & Blank 1998 \\
\hline Solinus (Gaius Julius Solinus), De Mirabilibus Mundi (MM) & Latin Library 2012 \\
\hline Strabo, Geography & Perseus 2012 \\
\hline Valerius Maximus, Factorum et Dictorum Memorabilium & Perseus 2012 \\
\hline
\end{tabular}




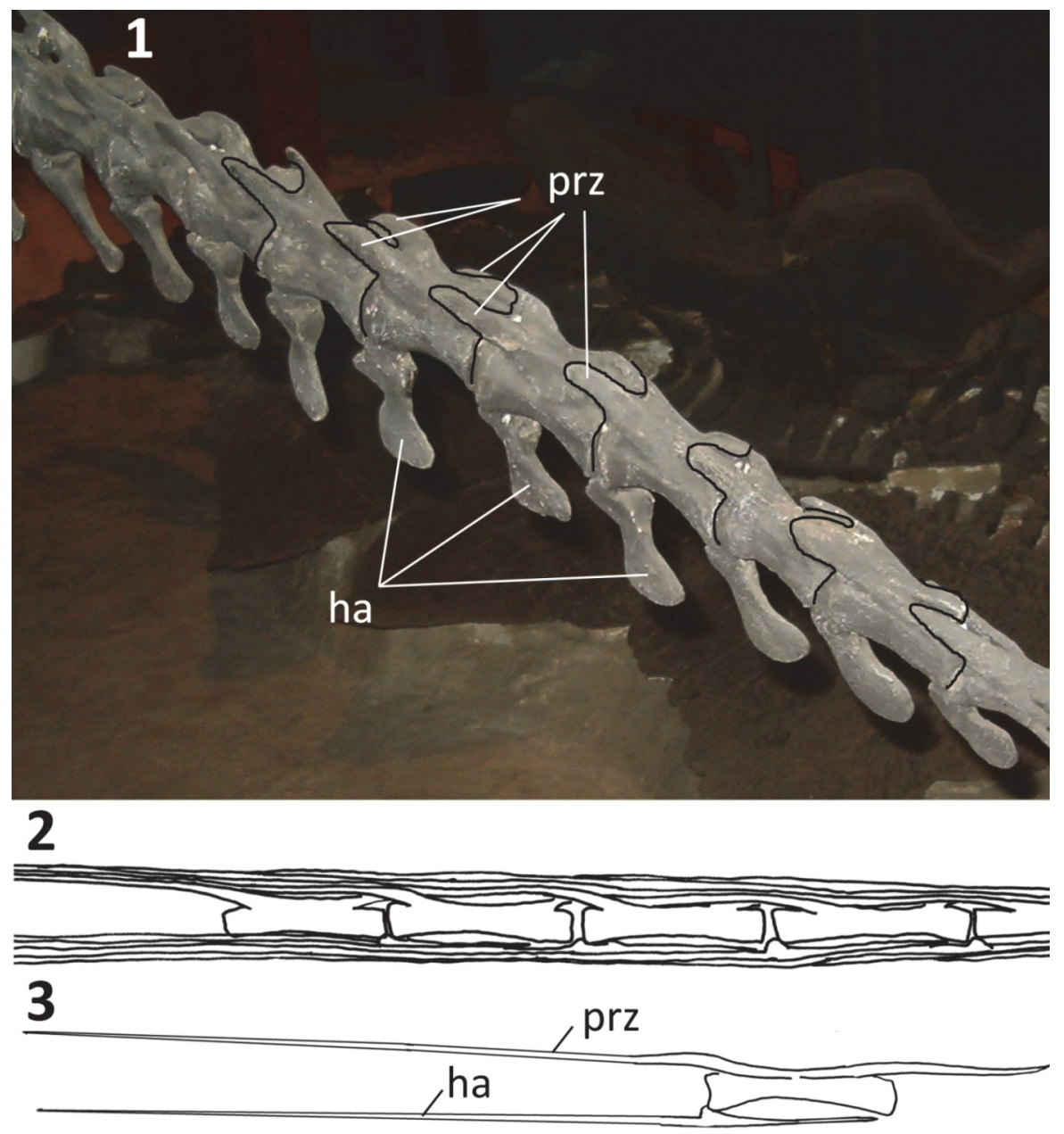

FIGURE 1. Tail skeletons of a theropod dinosaur and a pterosaur, showing the bony processes that restrict lateral bending and therefore prevent tail coiling; anterior is to the left. 1.1. The theropod dinosaur Allosaurus fragilis. 1.2. The long-tailed pterosaur Rhamphorhynchus gemmingi, modified from a published illustration Wellnhofer (1975, Figure 7). 1.3. A single tail vertebra and hemal arch of $R$. gemmingi. prz = prezygapophysis, ha $=$ hemal arch.

Coils in a carnivorous drakōn or draco are important to note, because the vertebral column of a carnivorous dinosaur lacks the ability to form coils. The torso is too short for coiling, and the hyposphene-hypantrum (wedge-in-socket) articulations between the dorsal vertebrae keep the spinal column stiff in the torso (Makovicky, 1997). The tail of a carnivorous dinosaur is also too stiff to coil, because on each middle and distal tail vertebra an elongate pair of prezygapophyses (forward-pointing prongs) clasps the preceding vertebra in a configuration that severely limits lateral movement (Figure 1.1). Pterosaur tails are also incapable of forming coils. The tails of pterodactyloid pterosaurs are too short to coil. In other pterosaurs, which have long tails, a framework of bony rods that consists of elongated prezygapophyses and extensions of hemal arches, runs lengthwise down the tail and prevents bending (Wellnhofer, 1991) (Figure 1.2-3).

\section{THE DRAGONS OF PLINY AND OTHER ENCYCLOPEDISTS: DINOSAURS?}

Several Greco-Roman authors included the dragon (drakōn, draco) in encyclopedias of animals or of nature in general. The earliest detailed description of the dragon in such a work is that of the first-century Roman author Pliny the Elder in Naturalis Historia.

Various YEC authors claim that Pliny's description of the dragon is a description of a dinosaur (Niermann, 1994; Petersen, 2002; Isaacs, 2010). However, it is not. According to Pliny, the draco is a serpens (snake) (NH 8.26) that is nonvenomous (NH 29.21) and is found in India $(\mathrm{NH}$ 8.15) and Aethiopia ( $\mathrm{NH} 29.21)$, the Roman term 

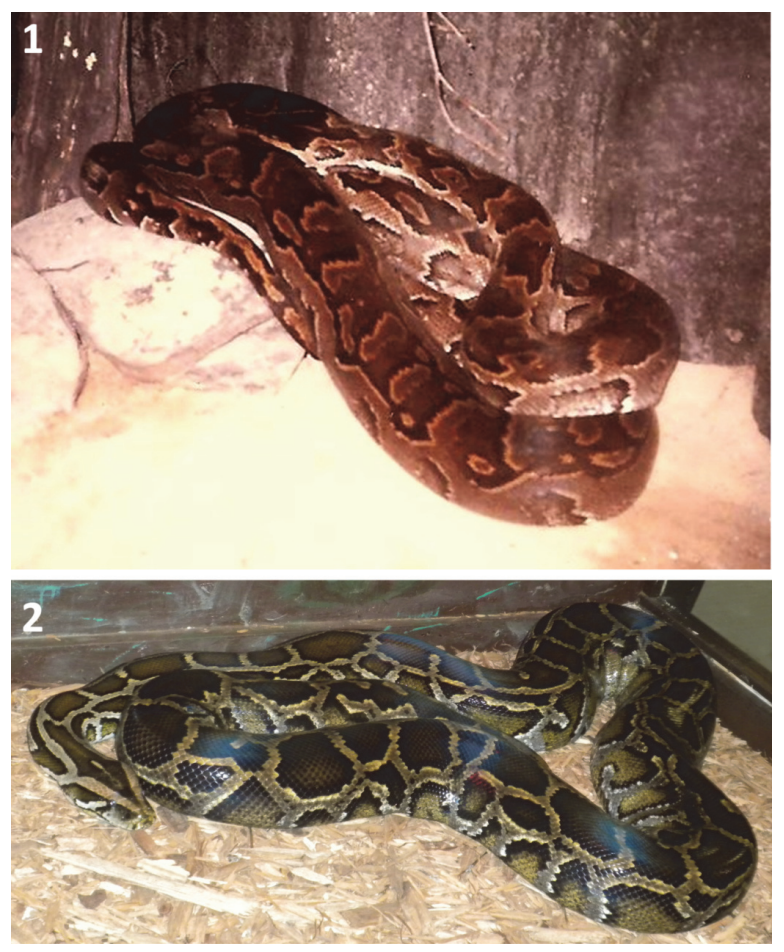

FIGURE 2. The draco of Pliny: African and Indian pythons. 2.1. African rock python (Python sebae). 2.2. Indian rock python (Python molurus).

for Africa south of Egypt (Anthon, 1878). It is 20 or more cubits long (NH 8.15); this is a length of 29 feet $(8.87 \mathrm{~m})$, given that a Roman cubit was 1.4562 English feet (Anthon, 1878). The draco is carnivorous and kills its prey after first coiling around it (NH 8.12).

Pliny's description of the draco-a large, nonvenomous, constricting snake from Africa and India-is consistent with the python. The African rock python (Python sebae) and the Indian rock python ( $P$. molurus) are very similar and could easily be mistaken for a single species (Figure 2). Both grow to lengths beyond 20 feet (Villiers, 1950; Das, 2010). Pliny's assertion that the draco constricts elephants (NH 8.15) is easily understood as a record of folklore involving an exaggeration of the python's size, but even this folklore acknowledges that a draco cannot survive the attempt to kill an elephant $(\mathrm{NH} 8.14,8.15)$ and is therefore not a habitual elephant-eater.

Other Greco-Roman encyclopedic works acknowledge the existence of the dragon and describe it as a type of snake. The earliest example is Aristotle's History of Animals, which mentions the drakōn only in passing. According to Aristotle, the eagle is the enemy of the drakōn, because the eagle eats snakes (opheis) (HA

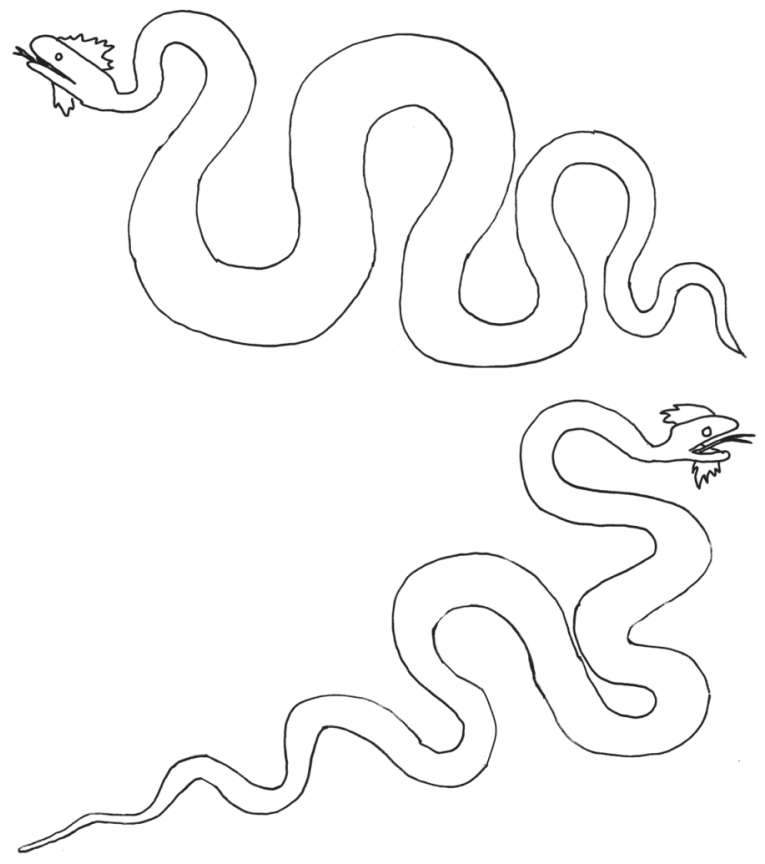

FIGURE 3. Snakes in Roman wall paintings, with the crests and wattles of roosters, from two houses in Pompeii (from Grant, 1979, unnumbered figures).

9.2.4). This shows that Aristotle considered the drakōn a type of snake.

Another example is Aelian's third-century work On the Characteristics of Animals. It is an uncritical compilation of folklore and rumor mixed with occasional fact, but its drakōn is an identifiable animal. Aelian's drakōn is scaly (ChA 14.12), hisses (ChA 6.63, 14.39), is found in Aethiopia (ChA 2.21) and India (ChA 6.21, 15.21), is said to kill elephants (ChA 2.21, 6.21), and kills by strangling its prey with its coils (ChA 6.21). It is therefore the same as Pliny's draco: the python. Aelian also added questionable details such as its presence in Phrygia (modern-day Turkey) (ChA 2.21), which will be addressed in another section below; its attainment of lengths above 100 feet (ChA 15.21); and the male's possession of a crest and wattle (ChA 11.26). Although the crest and wattle seem to belie the interpretation of the drakōn as a snake, the Romans frequently depicted snakes with rooster combs and wattles (Figure 3), so this detail is actually consistent with the snake interpretation. In fact, such depictions were common enough to make Pliny (NH 8.13) voice exasperation that a person-specifically King Juba II of Numidiacould believe that a draco would actually have a crest.

The third-century author Solinus also mentions the dragon in De Mirabilibus Mundi (Wonders 
of the World). He repeats Pliny's elephant-killing description (MM 25.11-14), which indicates that Solinus' draco is the same as Pliny's. He also adds that the draco has a narrow throat and protrudes its tongue (MM 30.15), a statement strange for a carnivorous dinosaur but consistent with a snake.

\section{THE DRAGONS OF PHRYGIA: DINOSAURS?}

One YEC author claims that an ancient account of dragons in Phrygia, which suck birds out of the sky, refers to living dinosaurs (Niermann, 1994). However, a reading of the ancient account itself reveals that the "dragons" in question are meant as snakes. The account is from Aelian's On the Characteristics of Animals. According to Aelian, in Phrygia the drakōn grows to a length of six orguias (ópyuıòs), which is about 61 feet or $18.5 \mathrm{~m}$ (a Greek orguia $=6.0675$ English feet [Anthon, 1878]). Every midsummer afternoon the Phrygian dragons near the Rhyndacus River leave their lairs, raise their necks while keeping their coils on the ground, and draw birds into their open mouths with their breath. After sundown, they kill sheep and eat shepherds (ChA 2.21). Aelian's account is apparently an elaborated version of an account by Metrodorus, a Greek writer from the second and first centuries B.C., whose writings no longer survive. According to Pliny, Metrodorus mentioned serpentes (snakes) from near the Rhyndacus River that would seize and swallow birds flying above them (NH 8.16). Aelian's reference to coils and Pliny's use of the word serpentes identify the Phrygian drakontes as snakes, not dinosaurs.

The gigantic Phrygian snakes are imaginary. The region has no snakes large enough to eat a sheep or a human, and no animal can inhale strongly enough to draw flying birds out of the sky.

\section{THE VATICAN HILL DRAGON: A DINOSAUR?}

One YEC author claims that Pliny records the finding of a child in the body of a dragon that was killed on Vatican Hill during the reign (A.D. 41 - 54) of Emperor Claudius, and that this dragon was a living dinosaur (Niermann, 1994). However, Pliny does not call the animal in question a draco. He calls it a boua (NH 8.16). Solinus mentions the same child-eating animal, calls it a boa, mentions that the boa was common in Calabria (southern Italy), and lists the boa as a type of serpens ( $M M$ 2.31-34). The animal was therefore a snake, not a dinosaur.

The boualboa is possibly another imaginary snake, because today Italy has no snakes large enough to devour a child, and because both Pliny and Solinus agree that the boualboa is named after its habit of suckling milk from cows (bos), which no snake actually does. However, the Greek author Strabo (64/63 B.C. - A.D. 24) mentions that large snakes were imported to Rome from India during the reign (27 B.C. - A.D. 14) of Augustus Caesar (Geography 15.1.73). It is therefore possible that, as in present-day Florida, escapee populations of exotic pythons were present in Pliny's first-century Italy and Solinus' third-century Italy, and that the original "boas" were pythons.

\section{THE BAGRADAS RIVER DRAGON: A DINOSAUR?}

According to two YEC authors, a dragon in Africa that attacked a Roman military unit that was led by the consul Regulus, was a living dinosaur (Niermann, 1994; Woetzel, 2012). Ancient Roman writers place the alleged incident in 256 B.C., during the First Punic War, when Regulus' unit was camped at the Bagradas River near Carthage (Stothers, 2004). The most detailed surviving account is from the fourth- to fifth-century historian Paulus Orosius (Historiae Adversum Paganos 4.8), who probably got it from a now-lost text written by Livy in the late first century B.C. (Stothers, 2004). According to Orosius, the animal ate several soldiers but was finally killed with spears after a catapulted stone weakened its spine enough to stop its locomotion. Before this it had been crawling on its belly by using its ribs to move the belly scales as if they were feet. It had no actual feet. The lack of feet identifies the animal as a snake, and all the Roman authors who mention the incident-Pliny the Elder (NH 8.16), the first-century author Florus (Epitome Rerum Romanorum 1.18.12), the firstcentury author Valerius Maximus (Factorum et Dictorum Memorabilium 1.1.14), the second-century author Aulus Gellius (Noctes Atticae 7.3.1), and Orosius-confirm this by calling the animal a serpens. None of them call it a draco.

The Roman authors who mention the snake's length (Pliny, Valerius, Aulus Gellius, and Orosius) all give it as 120 feet. Aulus Gellius and Orosius add that its skin was brought to Rome, and Pliny says that the skin and jaws were preserved in a temple there until the Numantine War $(143-133$ B.C.). Although that tidbit gives the story the sound of authenticity, every author who wrote about the incident or the skin was at least one century too young to have visually confirmed the existence of the alleged skin. The possibility therefore exists that the event and the giant snake were imaginary. 

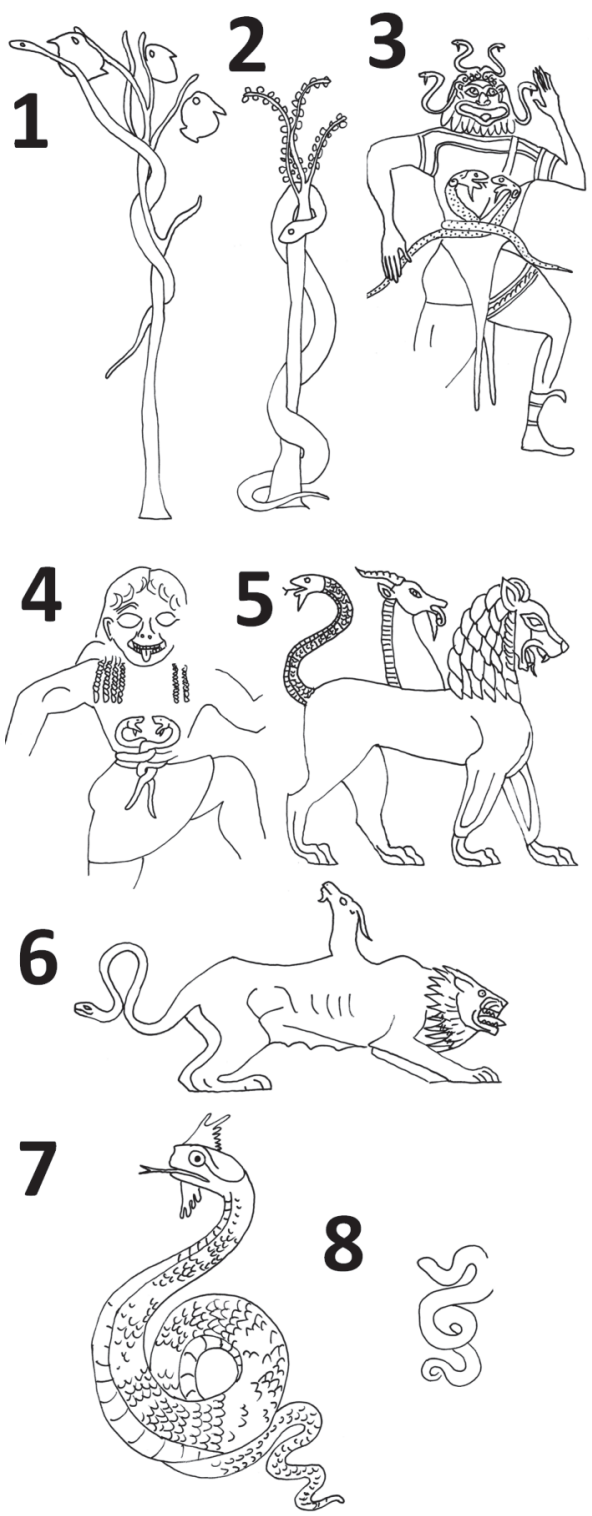

FIGURE 4. Examples of the drakōn in ancient Greek art depicting scenes from mythology. Note that they are all snakes, and that the ancient Greeks often added beards and occasionally rooster crests to snake depictions. 4.1. The drakōn of the Hesperides, which was slain by Herakles, from a Greek vase from ca. 500 B.C. (Carpenter, 1991, Figure 212). 4.2. The drakōn of the Hesperides, from a Greek vase from the fifth century B.C. (Carpenter, 1991, Figure 213) 4.3. The drakontes that made up the belt of a gorgon, from a Greek jug from the sixth century B.C. (Woodford, 2003, Figure 95). 4.4. The drakontes that made up the belt of a gorgon, from a Greek temple relief from the sixth century B.C. (Carpenter, 1991, Figure 155). 4.5. The drakōn that was the tail of the Chimaera, from a relief on a shield band panel from the sixth century B.C. (Carpenter, 1991, Figure 164).
Stothers (2004) lists other possibilities. One is that the animal in question was not actually a snake, but this is contradicted by the ancient account, as shown above. Another is that the 120 "feet" were actually 120 pairs of ribs, but this is implausible because pythons have about 300 ribs (Cohn and Tickle, 1991). A third possibility is that the snake really was that long. In support of this he cites a number of ancient authors who claimed that northern Africa had snakes much longer than today's African rock pythons, but none of those authors were eyewitnesses to the existence of snakes that long. A fourth possibility is that the size of the Bagradas snake was exaggerated.

As noted by Woetzel (2012), John of Damascus, a Syrian monk of the late fifth and early sixth century, argues that the drakōn exists and mentions the Bagradas incident in On Dragons. However, John of Damascus says that the drakōn is a very large type of snake (ophis). He proffers the Bagradas creature as an example of a drakōn and adds that the drakōn lacks venom. This makes it clear that even as late as the fifth century, the term drakōn was used in reference to enormous, nonvenomous snakes, and that the Bagradas creature was understood as a snake, not a dinosaur.

\section{THE DRAGONS OF BEROSSUS}

One YEC author claims that dragons were dinosaurs, and dragons must be from historical times, because the Babylonian historian Berossus, who wrote in Greek, wrote of dragons (Morris, 1999). That is incorrect. There is no mention of the drakōn in any of the surviving fragments of Berossus' writings, nor in any of the ancient comments on his works (Cory, 1828). In his creation story Berossus did mention various strange-looking creatures: men with two wings; men with four wings; men with two heads; hermaphrodites; men with goat horns and goat legs; centaurs; bulls with human heads; dogs with four bodies and fish tails; and a creature that resembled a fish joined to a man (Cory, 1828). However, he calls none of these creatures dragons, nor are they dinosaurs.

FIGURE 4 (continued). 4.6. The drakōn that was the tail of the Chimaera, from a Greek relief from the fifth century B.C. (Buxton, 2004, unnumbered figure). 4.7. The drakōn slain by Kadmos, from a Greek vase from the fifth century B.C. (Buxton, unnumbered figure). 4.8. The drakaina slain by Apollo, from a Greek coin from the fifth century B.C. (Carpenter,1991 Figure 104). 

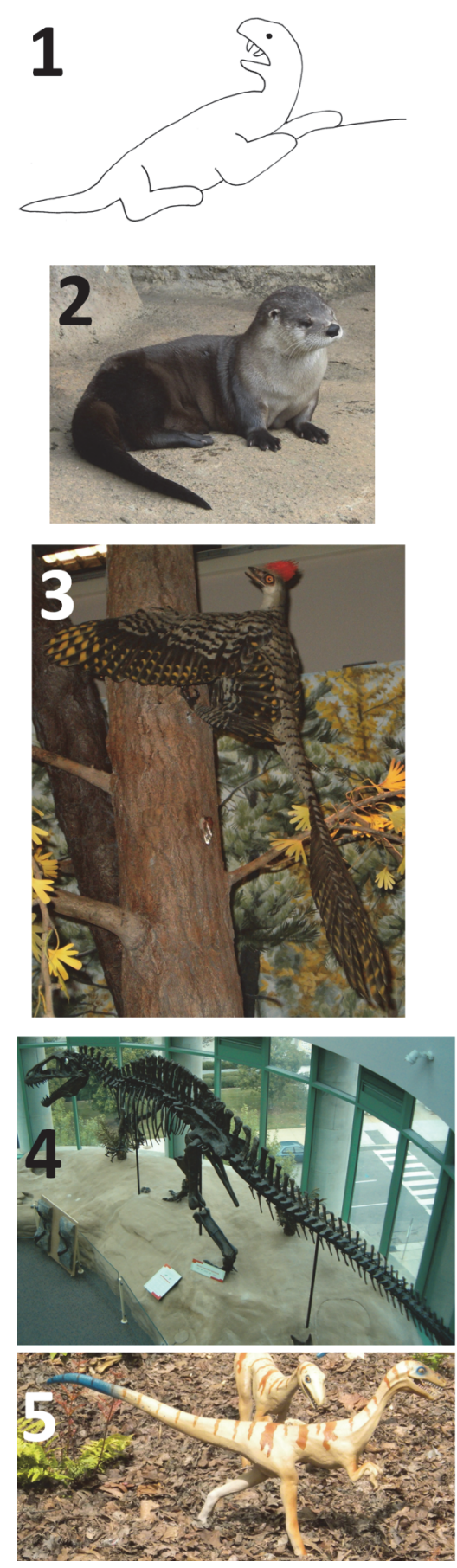

FIGURE 5. The krokodilopardalis in the Nile mosaic of Palestrina, compared to an otter and to three representative theropod dinosaurs. Note the resemblance between the krokodilopardalis and the otter, and the marked difference between the body plan of the krokodilopardalis and the theropod body plan. 5.1. The krokodilopardalis (Meyboom, 1995, Figure 18). 5.2. An otter (Lontra canadensis). 5.3. Reconstruction of he dromaeosaurid theropod Microraptor gui. 5.4. Skeleton of the carnosaurian theropod Acrocanthosaurus atokensis. 5.5. Reconstruction of the compsognathid theropod Compsognathus longipes.

\section{THE DRAGON OF IPHICRATES: A DINOSAUR?}

In a section on alleged dinosaur sightings, one YEC author (Niermann, 1994) quotes a book on dragons (Blumberg, 1980), which mentions "another African monster described by the geographer Iphicrates. His dragon had grass growing on its back. It was so big that Iphicrates said people mistook it for a meadow." The quote is erroneous on several counts. The writings of Iphicrates, an Athenian general of the fourth century B.C., have not survived, but his dragon statement was recorded by Strabo: "Above Mauretania, on the exterior sea (the Atlantic), is the country of the western Ethiopians...Iphicrates...speaks also of large drakontes, and says that even grass grows upon their backs" (Geography 17.3.5). There is no mention of meadows, and Iphicrates' drakontes are a type of animal, not a single individual. In a later

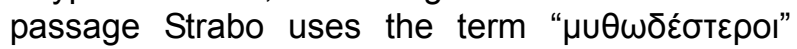
(mythōdesteroi: mythical, of fable) to describe the idea that Libyan drakontes have grass growing on their backs (Geography 16.6.16), revealing that he doubts its veracity. In any case, there is nothing in the wording of these passages that suggests the drakontes in question are dinosaurs or precludes them from being meant as snakes.

\section{ALEXANDER'S DRAGONS: DINOSAURS?}

In support of the idea that humans encountered live dinosaurs, several YEC authors mention that Alexander the Great is said to have encountered dragons that were kept in caves in India and venerated by the locals (Ham et al., 1991; Niermann, 1994; Ham, 2006; Gilmer, 2011), and one simply mentions that Alexander encountered dragons (Morris, 1999). The ancient authors of serious biographies of Alexander, who incorporated the now-lost memoirs of people who had traveled with Alexander, were Diodorus Siculus (first century B.C., Bibliotheca Historica), Quintus Curtius Rufus (first century A.D., Historiae Alexandri Magni), Arrian (first and second centuries A.D., Indika), Plutarch (first and second centuries A.D., Alexander), and Justin (second or fourth century A.D., Historiarum Philippicarum). None of these authors mention Indian drakontes or draconum, although Curtius Rufus (HAM 6.4.18) and Justin (HPh 17.75.3) mention enormous opheis/serpentes near the Caspian Sea, and Justin says that some Indian opheis reach 16 cubits (HPh 17.90.1). The Indian 

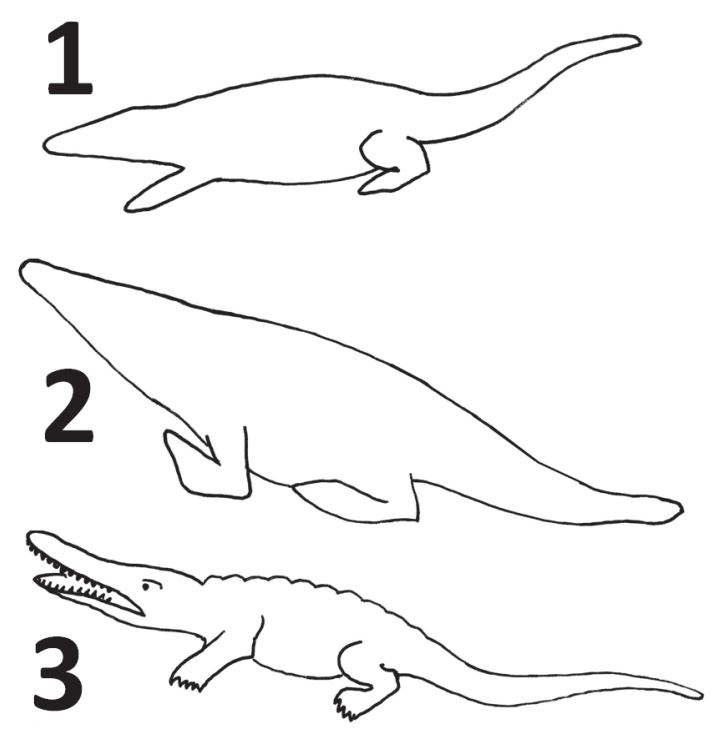

FIGURE 6. An alleged dinosaur (actually a crocodile) in a Pompeii wall painting, compared with other crocodiles in Roman wall paintings. Note that in all cases, the crocodiles are not portrayed with great realism but are dumpy and almost cartoonish. 6.1. The alleged dinosaur (Zillmer, 1998, Figure 91). 6.2. Crocodile in a Roman relief from the first century B.C (Meyboom, 1995, Figure 38). 6.3. Crocodile in a Roman mosaic from the first century B.C (Meyboom, 1995, Figure 28).

cave drakōn story is therefore more likely folklore than history.

Much folklore about Alexander the Great had been invented and circulated through the GrecoRoman world by the early centuries A.D. The Indian cave drakōn story is apparently one of these stories. It is first mentioned by Aelian (ChA 15.21), whose work is full of impossible animal tales. The interpretation that the Indian cave drakontes were imaginary is supported by Aelian's assertion that their eyes were as large as a Macedonian shield, which was about $60-70 \mathrm{~cm}(24-28$ inches $)$ in diameter (Connolly, 1998), several times larger than the eyes of any land animal, including the largest dinosaurs. A Macedonian shield is halfagain the diameter of the eye of a giant squid (Ellis, 1999), which has the largest known eyes among extant animals, larger even than those of elephants and whales. It is also important to note that nothing in Aelian's Alexander tale precludes its drakōn from being meant as an enormous snake, which is Aelian's typical use for the term drakōn.

\section{DRAGONS IN GREEK MYTHOLOGY: DINOSAURS?}

According to one YEC author, dragons in Greek mythology suggest that the ancestors of the Greeks were threatened by live dinosaurs (Rouster, 1978). However, the ancient Greeks understood each drakōn in their mythology as a snake. Examples of creatures in Greek myth that ancient Greek authors called a drakōn include the drakaina (female drakōn) Python, which was slain by Apollo (Anonymous, Hymn to Apollo, line 300); the drakōn slain by Kadmos (Apollodorus, Library 3.4.1); the drakōn that guarded the apples of the Hesperides, slain by Herakles (Library 2.5.11); the drakōn that guarded the Golden Fleece (Library 1.9.16); the tail of the Chimaera (Hesiod, Theogony, lines 322-323); and the belts of the Gorgons (Hesiod, The Shield of Herakles, lines 233-234). In each case, ancient Greek artwork depicts the creature as a snake (Figure 4). Even in mythical texts, a drakōn may be called a drakōn in one line and an ophis in the next (Theogony, lines 323 and 825; Homer, Iliad, lines 12.202 and 12.208; Library 2.5.11), revealing that the drakōn was considered a snake. The "dragons" of Greek mythology are therefore snakes, not dinosaurs.

Rouster (1978) lists Hercules, Apollo, and Perseus as dragon-slayers of Greek mythology. However, although the creatures slain by Hercules and Apollo were called a drakōn and a drakaina, the one slain by Perseus was something different: a marine monster called a kñTos (kētos). This cannot have been based on a dinosaur, because no dinosaur was marine. Greek depictions of the kētos vary, but in no case does it resemble a dinosaur or any of the various Mesozoic marine reptiles (Shepard, 1940).

\section{THE KROKODILOPARDALIS: A DINOSAUR?}

Two YEC authors claim that the Nile Mosaic of Palestrina, created in the second century B.C. (Meyboom, 1995), depicts a group of Ethiopians hunting a dinosaur (Gilmer, 2011; Woetzel, 2012). In the mosaic the animal is labeled KPOKO $\triangle \mathrm{I} \wedge \mathrm{O} \cap \mathrm{AP} \triangle \mathrm{A} \wedge \mathrm{IC}$ (krokodilopardalis: crocodile-leopard), a term that is unknown outside this mosaic. According to Gilmer (2011), the term could refer to the combination of reptilian traits with mammal-like limbs and movement that is present in dinosaurs. He specifically identifies the krokodilopardalis as a theropod dinosaur. However, its quadrupedal limb proportions are unlike those of 

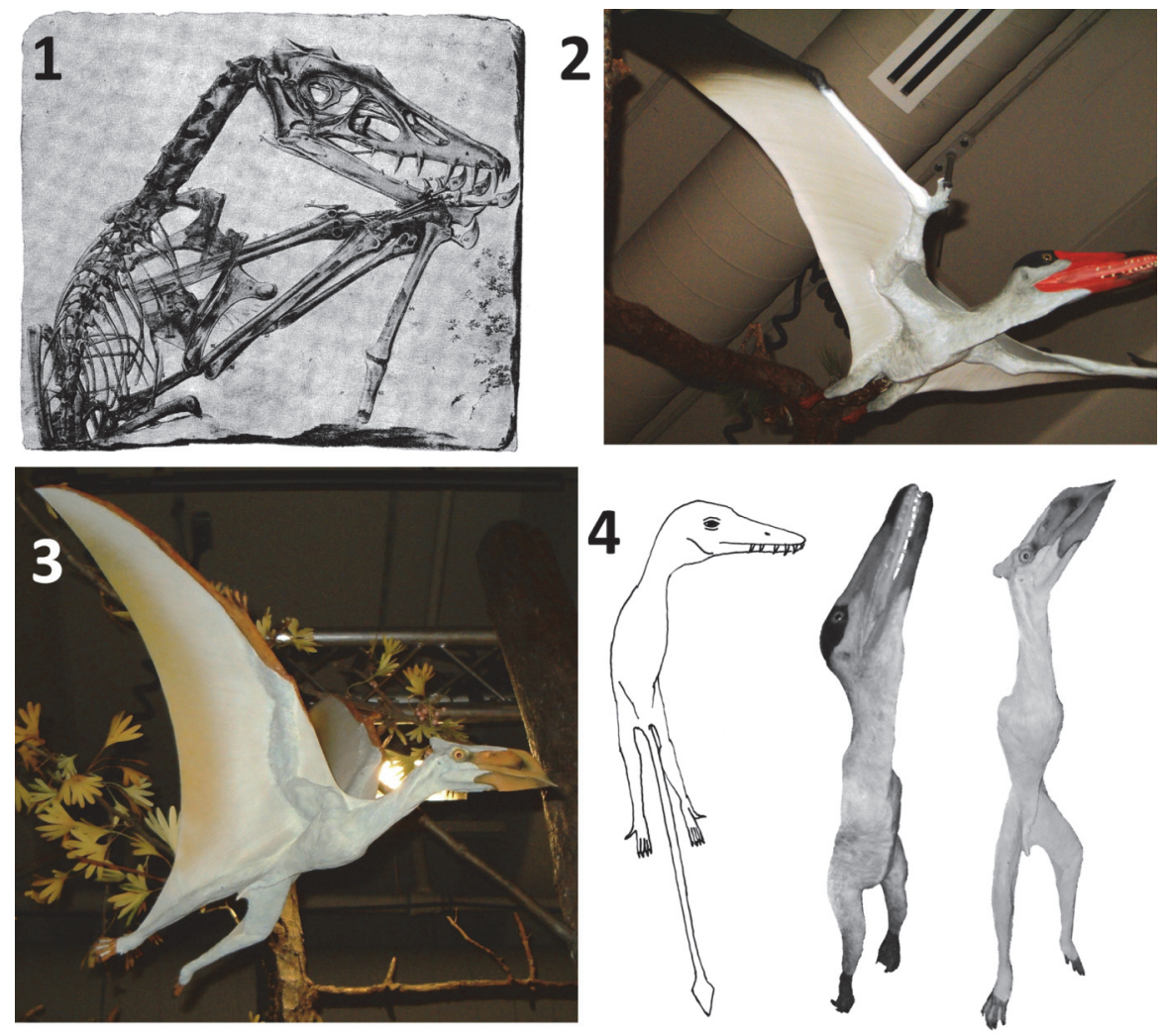

FIGURE 7. A long-tailed pterosaur, a short-tailed toothed pterosaur, and a short-tailed toothless pterosaur. These pictures show that pterosaurs of all three sorts do not have the form of a water snake, and that in all three the body plan is more birdlike than snakelike, even without wings. 7.1. Scaphognathus crassirostris, skeleton as preserved and illustrated by Goldfuss (1831). 7.2. Haopterus gracilis, reconstructed according to a complete skeleton. 7.3. Sinopterus dongi, reconstructed according to a complete skeleton. 7.4. The previous three pterosaurs, with wings removed, to show that they are not snakelike at all and therefore Herodotus' description of flying serpents as "having the form of the water snake" is inapplicable to pterosaurs; the bodily form of S. crassirostris is reconstructed according to the complete skeleton of a juvenile (Wellnhofer, 1991, unnumbered figure), with the proportions altered to match those of the adult of a closely related species: Rhamphorhynchus gemmingi.

theropods, which were bipeds, and its overall body shape is very unlike that of a theropod (Figure 5).

Another author has suggested that the krokodilopardalis is a monitor lizard (Meyboom, 1995), but it does not resemble a lizard, and elsewhere in the mosaic is a lizard that is depicted realistically enough to show that the artist knew how to depict a lizard and make it look like one. The artist was capable of depicting distinct fingers such as those of a theropod, because he did so in his rendition of the crocodile and the lizard on the same mosaic, but the limbs of the krokodilopardalis end not in distinct fingers but in mammalian paws such as are present in members of Carnivora. The brown color of the krokodilopardalis is consistent with mammalian fur. Its limb proportions and bodily shape strongly resemble those of an otter (Figure 5). The thick, pointed tail is shaped particularly like that of an otter and is about the right relative size, and the lack of visible ears is consistent with the tiny ear size of an otter. Even the name "crocodile-leopard" is consistent with an otter, if it is interpreted as expressing a crocodile's aquatic habits in an animal with the overall body plan of a carnivorous mammal. It is certainly as appropriate a composite term for an otter as the Latin camelopardalis (camel-leopard) is for the giraffe.

The upper section of the mosaic, which includes the krokodilopardalis, represents Nubia (present-day Sudan and Ethiopia) (Meyboom, 1995), a region inhabited by a very large species of otter: Aonyx capensis, the African clawless otter, which reaches a weight of about 75 pounds and a length of over five feet (Kingdon, 1997). The animal in the mosaic looks larger than that relative to the nearby Ethiopians, but the people and animals and objects in the mosaic are not to scale. As depicted, the Ethiopians are tall enough to place their raised 
palms on the roofs of the three-story building in the center of the painting, the camel is too large to fit into said building and is larger than the rhinoceros, the length of the lions exceeds the height of the three-story building, and the crocodile-if it were strung up vertically with its snout in the air and its tail tip on the ground-would tower over the trees.

Smaller otters are depicted in another portion of the upper section of the mosaic and are labeled ENYAPIC (enydris: otter). Sudan and Ethiopia are inhabited by ordinary-sized otters in addition to the huge clawless otter (Kingdon, 1997). It is therefore possible that only the large species was called krokodilopardalis. Another possibility is that the krokodilopardalis is not an otter but an imaginary creature. Whichever the case, the creature in the mosaic bears no resemblance to a dinosaur, theropod, or otherwise.

\section{POMPEII DINOSAUR?}

One YEC author suggests that an aquatic animal in a Pompeii wall painting is a dinosaur (Zillmer, 1998). However, the animal has no specifically dinosaurian features, such as vertical limbs that carry the torso clear of the ground. Comparison with other Roman wall paintings shows that the animal is a crocodile (Figure 6). It has the same shape that is present in stylized crocodiles in other Roman wall paintings, in which more detail is present so that identification of the animal as a crocodile is certain.

\section{FLYING SERPENTS: PTEROSAURS?}

Several YEC authors cite the winged serpents mentioned by Herodotus as evidence for human encounters with living pterosaurs (Taylor, 1987; Goertzen, 1998; Petersen, 2002; Woetzel, 2006; Butt and Lyons, 2008; Lyons and Butt, 2008; Stuckwish, 2009; Isaacs, 2010; Gilmer, 2011). Herodotus says (Histories $2.75,2.76,3.107$ ) that he came to a place near Buto, a city in the Nile delta (Anthon, 1878), in "Arabia"-which, to the ancient Greeks, included both present-day Arabia and northeast Egypt up to the Nile (Anthon, 1878)_to ask about

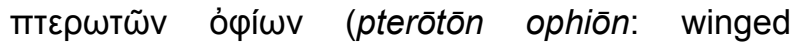
snakes). There he saw heaps of snake bones too many to count. He heard that to collect frankincense, Arabians had to use storax smoke to drive the winged snakes out of the frankincense trees. $\mathrm{He}$ also heard that each spring the winged snakes fly toward Egypt but are killed by birds called ibises before arrival. According to Herodotus the winged

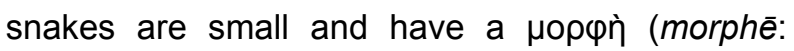
shape, form) like that of the üठpos (hydros: water snake of the genus Natrix) with wings that are not feathered but resemble those of a bat.

The batlike wings have convinced several YEC authors that Herodotus was speaking of pterosaurs, which, like bats, had wings of skin rather than of feathers. However, Herodotus' statement that the winged snakes have the form of a water snake is incompatible with a pterosaur. Pterosaurs have beaklike snouts; legs and feet with clawed toes; and skin covered in hairlike filaments, not scales (Wellnhofer, 1991). They would therefore have been better described as having the form of a furry bird or a long-snouted bat, not a snake. As shown in Figure 7, to liken a pterosaur to a snake is absurd. Herodotus' winged snakes were therefore not pterosaurs.

It is possible that the winged snakes were imaginary. Herodotus saw snake skeletons but did not record having seen the flying snakes themselves. If they did exist, then, given his description, they were probably some type of actual snake with winglike extensions of skin (hence the likening to bat wings). As it happens, the geographic area in question does have such snakes: cobras (genus Naja), which spread extensions of the neck skin when agitated. Most species of Naja readily climb trees (Spawls and Branch, 1995), which is compatible with their presence in frankincense trees.

Aristotle also mentioned the winged serpents, and two YEC authors (Taylor, 1987; Petersen, 2002) cite Aristotle's writing as evidence for human encounters with pterosaurs. However, Aristotle's passing mention, in a passage on animal locomotion, that "Feathered-winged and skin-winged animals are bipeds or lack feet, for they say that there are serpents [opheis] of such a kind [skin-winged] near Ethiopia" (HA 1.5.9) was not a firsthand account but a mere nod to what "they say" (they = Herodotus?). Aristotle mentioned the alleged flying serpents only to support the assertion that some winged animals lack feet. The lack of feet and the epithet opheis show that Aristotle was speaking of snakes, not pterosaurs.

One YEC author cites Strabo's mention of winged serpents as evidence for human encounters with pterosaurs (Taylor, 1987). However, Strabo did not claim that winged snakes existed. Rather, he included them in a list of misinformation about the east, prefacing the list with this statement: "All the country on the other side of the Hypanis [i.e., in India] is allowed to be very fertile, but we have no accurate knowledge of it. Either 


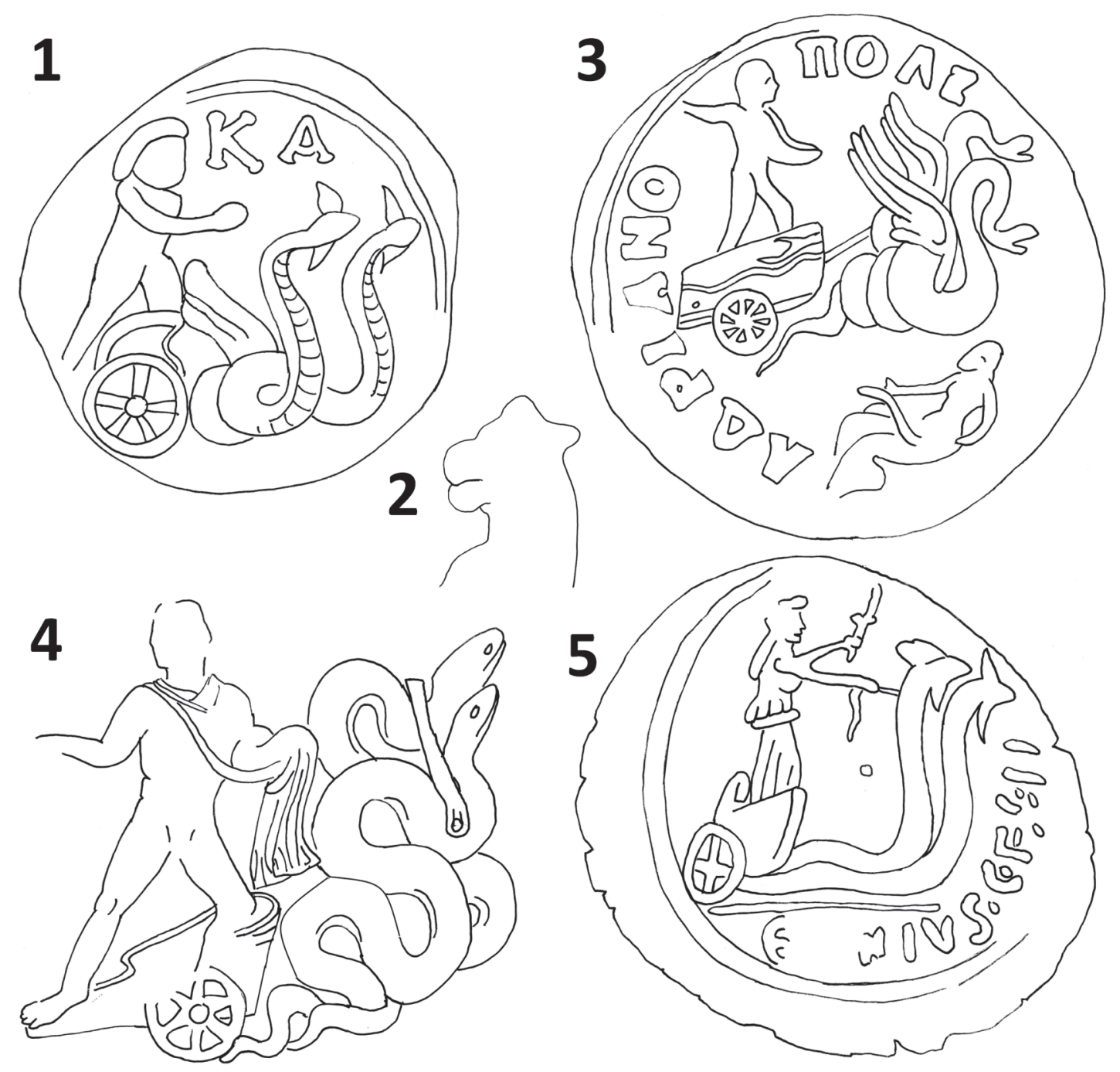

FIGURE 8. Two alleged representations of the pterosaur Scaphognathus crassirostris, and scenes of snakes pulling chariots in classical art. Note that the chariot-pulling "pterosaurs" are winged snakes with crests and wattles that resemble those of the chariot-pulling snakes in 8.5. Note also the lack of resemblance between $S$. crassirostris itself (in Figure 7.1) and the alleged S. crassirostris representations in 8.1 and 8.2. 8.1. A pair of alleged S. crassirostris pulling the chariot of Triptolemos in a Roman-Alexandrian coin (Goertzen, 1998, Figure 7). 8.2. Head of an Etruscan statue, allegedly of S. crassirostris (Goertzen, 1998, Figure 11). 8.3. Winged snakes pulling Triptolemos' chariot, on a Thracian coin from the second or third century A.D. (Sayles, 1998, unnumbered figure). 8.4. Wingless snakes pulling Triptolemos' chariot, on a Roman sarcophagus from the third century (Robert, 1919, Figure 433). 8.5. Wingless snakes pulling the chariot of the Roman goddess Ceres, on a Roman coin from the first century B.C. (Spaeth, 1996, Figure 5).

from ignorance or from its remote situation, everything relative to it is exaggerated or partakes of the wonderful" (Geography 15.1.37). He then listed several items that he considered to be misinformation, including stories of "serpents (opheis) of two cubits in length, with membranous wings like bats" that "fly at night, and let fall drops of urine or sweat, which occasions the skin of persons who are not on their guard to putrefy."
One YEC author lists other classical authors who mention the flying snakes of Egypt (Goertzen, 1998), but none of these classical authors describe the animals. Also, all based their accounts on hearsay, so none are eyewitness accounts. Cicero (first century B.C.) mentions that ibises kill and eat flying snakes (anguis) from the African desert that are brought toward Egypt by the Libyan wind (De Natura Deorum 101). Josephus (first century A.D.) 


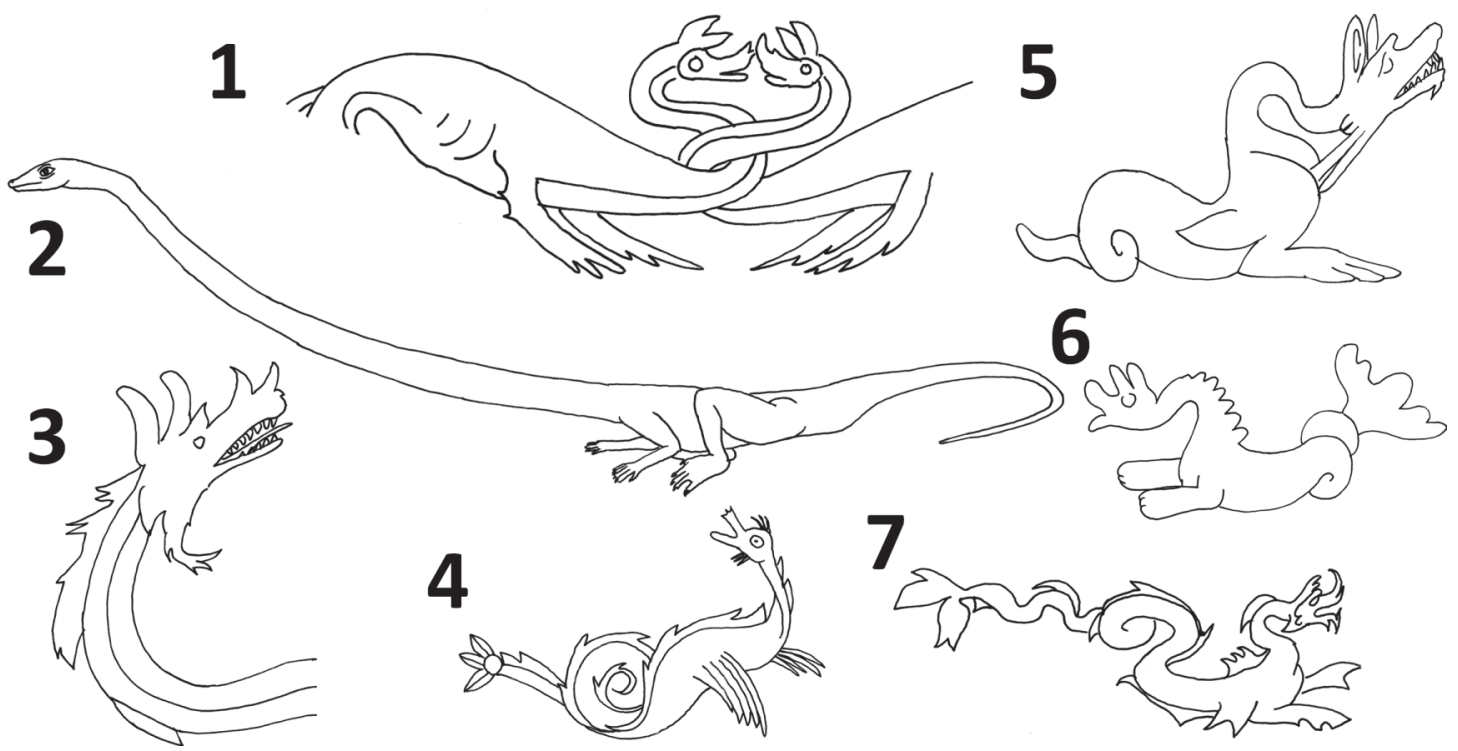

FIGURE 9. An alleged pair of Tanystropheus (actually a mythical sea monster called a cetus) in a second-century Roman mosaic in Lydney Park, England, compared with Tanystropheus and other examples of cete. Note that different artists portrayed the cetus with different, creative flourishes of anatomical interpretation, but the basic form of the cetus remains relatively uniform: a long-necked, long-eared, fluke-tailed marine creature with two fore-paws or foreflippers and no hind appendages, often with a coiled tail and a tufted nose. 9.1. The Lydney Park creatures (Taylor, 1987, unnumbered figure). 9.2. the Triassic reptile Tanystropheus longobardicus. 9.3. Cetus in a fourth-century mosaic from Syria (Dunbabin, 1999, Figure 173). 9.4. Cetus in a fourth-century Roman mosaic (Poeschke, 2010, Figure 1). 9.5. Cetus on a third-century Roman sarcophagus (Jensen, 2004, Figure 29). 9.6. Cetus on a fourth- or fifthcentury tray from Carthage (Lazaridou, 2011, Figure 14). 9.7. Cetus in a first-century Roman fresco (Woodford, 2004, Figure 8.9).

relates an apocryphal account of Moses using ibises to repel snakes (ophis), including mention that some Egyptian snakes could fly (Jewish Antiquities 2.10.2). Pomponius Mela (first century A.D.) mentions only that venomous, winged snakes (anguis) from the marshes are met by ibises (De Chorographica 3.82). Aelian (third century) mentions only that ibises prevent winged snakes (opheis) from entering Egypt (ChA 2.38). Solinus (third century) says that ibises eat venomous, winged snakes (anguium) from the marshes of Arabia (MM 32.33). Ammianus Marcellinus (fourth century) says that when flocks of venomous, winged snakes (anguium) come from the marshes of Arabia, ibises overcome them in the air and eat them (Rerum Gestarum 22.15.25-26). Due to the lack of description of the flying snakes, none of these accounts provides specific support to the idea that they were pterosaurs. It is possible that all are corruptions of Herodotus' account. In any case, all use the term ophis or anguis, which shows that these authors understood the animals as snakes. Also, the assertion that they are venomous is consistent with cobras.

\section{PTEROSAURS IN CLASSICAL ART?}

According to one YEC author, a Roman-Alexandrian coin from A.D. 137 or 138 depicts the longtailed pterosaur Scaphognathus crassirostris pulling the chariot of the mythological character Triptolemos (Goertzen, 1998). What the coin actually shows is a pair of winged snakes-complete with coils-pulling the chariot (Figure 8). According to Greek myth, the goddess Demeter gave Triptolemos a chariot drawn by a winged pair of drakontes (Apollodorus, Library 1.5.2). These are always depicted as snakes with feathered wings, and in Roman iconography a rooster's comb is often added (Figure 8). Both the feathers and the snakelike form are incompatible with pterosaurs.

The same YEC author illustrates an Etruscan bronze animal head and claims that it represents the pterosaur Scaphognathus crassirostris. His photo is too blurry to discern what animal is actually depicted, but its very short snout is unlike the long beak of $S$. crassirostris, and it has a pair of ear flaps (Figure 8.2). Among real animals, ear flaps are an exclusively mammalian trait. Soft-tissue structures are preserved in numerous pterosaur 
specimens (Wellnhofer, 1991), and in no case are there ear flaps.

\section{TANYSTROPHEUS IN A ROMAN MOSAIC?}

One YEC author illustrates a pair of longnecked creatures in a second-century Roman mosaic from Lydney Park, England, and suggests that they represent the Triassic reptile Tanystropheus (Taylor, 1987). However, Tanystropheus had four limbs, whereas the Lydney Park creatures have but two flippers (Figure 9). Also, the long, mammalian ear flaps on the Lydney creatures are inconsistent with a reptile. The noses of the Lydney Park creatures have tufted tips, and the torso of the creature on the viewer's left tapers posteriorly into a curved section that appears to be the beginning of a long, coiled tail. The Lydney Park creatures are actually examples of the cetus (Greek kñTos: kētos), a mythical sea monster common in Roman art and usually depicted with a long neck; long ear flaps; a single pair of paws or flippers; a long, coiling tail; and often a tufted nose, as in the Lydney Park mosaic (Figure 9). The word cetus or kētos was used for scary but real marine creatures such as sharks, seals, and whales (Scholfield, 1958), but it was also used for purely mythical monsters, and the Lydney Park beasts bear the morphology of the latter in Roman art.

\section{CONCLUSIONS}

None of the YEC claims of Mesozoic reptiles in Greco-Roman art are correct. The "dragons" are snakes. Even when no initial assumption that they are snakes is made, clues in the ancient texts identify them as snakes. The alleged pterosaurs are also snakes. Of the alleged Mesozoic reptiles pictured in Roman art, the krokodilopardalis is more like an otter than a theropod, the Pompeii "dinosaur" is a crocodile, Triptolemos' "pterosaurs" are snakes, and the Lydney Park "Tanystropheus" is a mythical sea monster.

\section{DISCUSSION}

If there is any evidence that ancient humans encountered living dinosaurs and pterosaurs, it is not in the Greco-Roman literature and art that has been cited by YEC authors, all of which is reviewed here. Greco-Roman use of the terms drakōn and draco is invariably consistent with reference to snakes, except in the few cases in which these terms are used for the weever fish. Interestingly, before Pliny's first-century work, there is no indication that the terms drakōn and draco were restricted to the python. Instead, as Bodson (1975) points out, the difference in usage between the terms drakōn and ophis in the most ancient Greek texts is that the term drakōn tended to be used in religious or mythical contexts, whereas the term ophis was used for snakes in ordinary contexts. This difference in usage is similar to that between the terms "serpent" and "snake" in English. However, writers after Pliny consistently imitated Pliny in making a taxonomic rather than contextual distinction between the terms drakōn/draco and the terms ophis/serpens/anguis. The latter set of terms was applied to snakes in general, and the former was restricted to the giant, constricting snakes of Africa and India.

By the fourth century, rumors that the draco could fly had begun, as recorded by Augustine of Hippo (On Psalm 148). This rumor was repeated in subsequent works on natural history by Isidore of Seville (sixth or seventh century; Etymologiae 7.4.4) and Vincent of Beauvais (thirteenth century; de Beauvais 1624), but it was not until the sixteenth-century work of Conrad Gessner that Herodotus' flying serpents were equated with the dragon (Gessner, 1589). By this time descriptions of the dragon had acquired so many absurdities that skeptics denied the existence of the beast, as testified in this seventeenth-century rhyme (Aubrey, 1881):

To save a Mayd, St. George the Dragon slew, A pretty tale, if all is told be true: Most say, there are no Dragons: and 'tis sayd, There was no George; 'pray God there was a Mayd.

This study reveals the need for more caution among YEC researchers when it comes to claims of human encounters with living animals known today only from Mesozoic fossils. It also underscores two methodological problems that commonly accompany such claims. One is the neglect to consult primary sources. Instead of consulting the ancient Greek and Roman sources to see what they actually said, most (although not all) of the YEC authors whose work is reviewed here instead used secondary or tertiary sources, and one (Niermann, 1994) even primarily consulted children's books. Examination of the ancient Greek and Latin literature itself could have prevented the errors that were made by these YEC authors. The second problem is one that I call dead varmint vision (DVV) or apnotheriopia (from the Greek roots ämvoos, 
apnoos: not breathing, dead; Onpíov, therion: beast; and ö $\psi$, ops: eye): a tendency to erroneously see fossil animals (dead varmints) in ancient works of art. DVV is often caused by a lack of familiarity with the mythology and the artistic and iconographic conventions of the culture that produced the art. Such familiarity could have prevented the mistaking of Triptolemos' snakes for pterosaurs or the Lydney Park cetus for a Tanystropheus. Likewise, familiarity with Native American artistic and iconographic conventions and mythology could have prevented several apnotheriopic misidentifications, by YEC authors, of "dinosaurs" and "pterosaurs" in North American rock art (Senter, 2012).

It would be highly advisable for future YEC studies on ancient literature to incorporate direct study of that literature, and for future YEC studies on ancient art to incorporate study of relevant stylistic conventions and mythology. Until these things are introduced into such studies, such studies will continue to commit easily avoidable errors.

As shown here, all published claims of evidence for human encounters with Mesozoic reptiles in Greco-Roman literature and art are easily demonstrated to be erroneous. However, it should be noted that the YEC paradigm does not depend on dinosaurs and pterosaurs in Greco-Roman literature and art. Those who hold the YEC view therefore ought to be able, in good conscience, to discard the idea of dinosaurs and pterosaurs in Greco-Roman literature and art.

\section{ACKNOWLEDGMENTS}

For help with the photographing of the Asian rock python in Figure 2, I would like to thank M. Gonsalves, reptile curator at Reptile Lagoon, South of the Border, South Carolina; and my wife and research assistant, J. Senter. I would also like to thank P. Wilkins for help with translation of Solinus, and two anonymous reviewers for suggestions that improved this paper.

\section{REFERENCES}

A Beka Book. 1994. Matter and Motion in God's Universe. A Beka Book, Pensacola.

Anthon, C. 1878. A New Classical Dictionary of Greek and Roman Biography, Mythology, and Geography. Harper and Brothers, New York.

Aubrey, J. 1881. Remaines of Gentilisme and Judaisme, p. 69. In Britten, J. (ed.), Remaines of Gentilisme and Judaisme.W. Satchell, Peyton, and Company, London.
Batdorf, B.R. and Porch, T.E. 2007. Life Science, Third Edition. BJU Press, Greenville, South Carolina.

Berkman, M.B. and Plutzer, E. 2011. Defeating creationism in the courtroom, but not in the classroom. Science 331:404-405.

Blank, D.L. 1998. Sextus Empiricus: Against the Grammarians. Clarendon, Oxford.

Blumberg, R. 1980. The Truth About Dragons. Four Winds, New York.

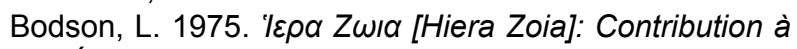
IÉtude de l'Animal Dans la Religion Grecque Ancienne. Académie Royale de Belgique, Brussels.

Butt, K. and Lyons, E. 2008. Dinosaurs Unleashed, Second Edition. Apologetics Press, Montgomery.

Buxton, R. 2004. The Complete World of Greek Mythology. Thames and Hudson, London.

Carpenter, T.H. 1991. Art and Myth in Ancient Greece. Thames and Hudson, London.

Cohn, M.J. and Tickle, C. 1999. Developmental basis of limblessness and axial patterning in snakes. Nature 399:474-479.

Connolly, P. 1998. Greece and Rome at War. Stackpole, Mechanicsburg, Pennsylvania.

Cooper, B. 1995. After the Flood: the Early Post-Flood History of Europe. New Wine Press, Chichester, England.

Cory, I.P. 1828. Ancient Fragments; Containing What Remains of the Writings of Sanchoniato, Berossus, Abydenus, Megasthenes, and Manetho. William Pickering, London.

Das, I. 2010. A Field Guide to the Reptiles of South-east Asia. New Holland, London.

Dunbabin, K.M.D. 1999. Mosaics of the Greek and Roman World. Cambridge University Press, Cambridge.

Ellis, R. 1999. The Search for the Giant Squid. Penguin, New York.

Gessner, K. 1589. Schlangenbüch. Froschow, Zurich.

Gilmer, J.E. 2011. 100 Year Cover-up Revealed. We Lived with Dinosaurs! Revised Edition. Authorhouse, Bloomington.

Gish, D.T. 1977. Dinosaurs, Those Terrible Lizards. Creation-Life, San Diego.

Goertzen, J. 1998. The rhamphorhynchoid pterosaur Scaphognathus crassirostris: a living fossil until the seventeenth century?, p. 253-269. In Walsh, R.E. (ed.), Proceedings of the Fourth International Conference on Creationism. Creation Science Fellowship, Pittsburgh.

Goldfuss, G. 1831. Beiträge zur Kentniss verschiedener Reptilien der Vorwelt. Breslau Universität, Bonn.

Gradstein, F., Ogg, J., and Smith, A. (eds.). 2004. A Geologic Time Scale 2004. Cambridge University Press, Cambridge.

Grant, M. 1979. Art and Life in Pompeii and Herculaneum. Newsweek, New York: Newsweek.

Ham, K. 2006. What really happened to the dinosaurs?, p. 149-176. In Ham, K. (ed.), The New Answers Book 1. Master Books, Green Forest, Arkansas. 
Ham, K., Snelling, A., and Wieland, C. 1990. The Answers Book. Master Books, El Cajon, California.

Hare, J.B. 2010. Internet Sacred Text Archive. www.sacred-texts.com (last accessed May 20, 2013).

Isaacs, D. 2010. Dragons or Dinosaurs? Creation or Evolution? Bridge-Logos, Alachua, Florida.

Jensen, R.M. 2004. Face to Face. Portraits of the Divine in Early Christianity. Fortress, Minneapolis.

Kingdon, J. 1997. The Kingdon Field Guide to African Mammals. A \& C Black, London.

Latin Library. 2012. The Latin Library. www.thelatinlibrary.com (last accessed May 20, 2013).

Lazaridou, A. 2011. Transition to Christianity. Art of Late Antiquity, 3rd - 7th Century AD. Alexander S. Onassis Public Benefit Foundation, New York.

Lyons, E. and Butt, K. 2008. The Dinosaur Delusion. Apologetics Press, Montgomery.

Makovicky, P. 1997. Postcranial axial skeleton, comparative anatomy, p. 579-590. In Currie, P.J. and Padian, K. (eds.), Encyclopedia of Dinosaurs. Academic Press, San Diego.

Mazur, A. 2005. Believers and disbelievers in evolution. Politics and the Life Sciences, 23(2):55-61.

Meyboom, P.G.P. 1995. The Nile Mosaic of Palestrina. E.J. Brill, Leiden.

Migne, J.-P. 1865. Patrologiae Cursus Completus. Patrologiae Graecae Tomus XCIV. Imprimerie Catholique, Paris.

Miller, J.D., Scott, E.C., and Okamoto, S. 2006. Public acceptance of evolution. Science 313:765-766.

Morris, J.D. 1999. Dinosaurs, the Lost World, \& You. Master Books, Green Forest, Arkansas.

Nelson, V. 2011. Dire Dragons. Untold Secrets of Planet Earth Publishing Company, Red Deer, Alberta.

Niermannn, D.L. 1994. Dinosaurs and dragons. Creation Ex Nihilo Technical Journal 8(1):85-104.

Parthey, G. 1867. Pomponii Melae De Chorographica Libri Tres. Frederick Nicholas, Berlin.

Perseus, 2012. Perseus Digital Library. www.perseus.tufts.edu (last accessed May 20, 2013).

Petersen, D.R. 2002. Unlocking the Mysteries of Creation, Premier Edition. Bridge-Logos, Alachua, Florida.

Poeschke, J. 2010. Italian Mosaics, 300 - 1300. Abbeville, New York.

Prothero, D.R. 2007. Evolution. What the Fossils Say and Why It Matters. Columbia University Press, New York.

Remacle, P. 2012. Aristote: Histoire des Animaux. http:// remacle.org/bloodwolf/philosophes/Aristote/tableanimaux.htm (last accessed May 20, 2013).

Robert, C. 1919. Die Antiken Sarkophag-reliefsim Auftrage des Deutschen Archaeologischen Instituts, Volume 1. G. Grote'sche, Berlin.
Rouster, L. 1978. The footprints of dragons. Creation Social Science and Humanities Quarterly 1978(Fall):23-28.

Sayles, W.G. 1998. Ancient Coin Collecting IV. Roman Provincial Coins. Krause, lola, Wisconsin.

Schaff, P. (ed.). 2012. Nicene and Post-Nicene Fathers. Christian Classics Ethereal Library. www.ccel.org (last accessed November, 2012).

Scholfield, A.F. 1958. Aelianus. On the Characteristics of Animals. Harvard University Press, Cambridge.

Senter, P. 2012. More "dinosaur" and "pterosaur" rock art that isn't. Palaeontologia Electronica 15(2.22A):1-14.

Shepard, K. 1940. The Fish-tailed Monster in Greek and Etruscan Art. privately printed, London.

Spaeth, B.S. 1996. The Roman Goddess Ceres. University of Texas Press, Austin.

Spawls, S. and Branch, B. 1995. Dangerous Snakes of Africa. Ralph Curtis, San Sanibel.

Stickney, A. 1881. M. Tullii Ciceronii De Natura Deorum. Ginn and Heath, Boston.

Stothers, R.B. 2004. Ancient scientific basis of the 'Great Serpent' from historical evidence. Isis 95:220-238.

Stuckwish, D. 2009. Biblical Cryptozoology: Revealed Cryptids of the Bible. Xlibris, Bloomington.

Taylor, P.S. 1987. The Great Dinosaur Mystery and the Bible. Cook Communications, Colorado Springs.

Thayer, B. 2003. Isidori Hispalensis Episcopi, Etymologiarum sive Originum. http://penelope.uchicago.edu/ Thayer/L/Roman/Texts/lsidore/12*.html (last accessed November, 2012).

Villiers, A. 1950. Les Serpents de l'Ouest Africain. Institut Français d'Afrique Noire, Dakar.

Vincent de Beauvais. 1624. Speculum Quadruplex sive Speculum Maius. Baltazaris Belleri, Douai.

Wellnhofer, P. 1975. Die Rhamphorhynchoidea (Pterosauria) der Oberjura-Plattenkalke Süddeutschlands. Palaeontographica Abteilung A 148:1-33.

Wellnhofer, P. 1991. The Illustrated Encyclopedia of Pterosaurs. Crescent, New York.

West, M. L. 2003. Homeric Hymns, Homeric Apocrypha, Lives of Homer. Harvard University Press, Cambridge.

Woetzel, D. 2006. The fiery flying serpent. Creation Research Society Quarterly 42:241-251.

Woetzel, D. 2012. Chronicles of Dinosauria. The History \& Mystery of Dinosaurs and Man. Master Books, Green Forest, Arkansas.

Woodford, S. 2003. Images of Myths in Classical Antiquity. Cambridge University Press, Cambridge.

Woodford, S. 2004. The Art of Greece and Rome. Cambridge University Press, Cambridge.

Zillmer, H. Z. 1998. Darwin's Mistake. Antediluvian Discoveries Prove Dinosaurs and Humans Coexisted. Frontier, Enkhuizen, Netherlands. 